Religious Studies, Page 1 of 21 @ Cambridge University Press 2018

doi:10.1017/S0034412518000653

\title{
Idolatry, indifference, and the scientific study of religion: two new Humean arguments
}

\author{
DANIEL LINFORD \\ Department of Philosophy, Purdue University, West Lafayette, IN 47907, USA \\ e-mail: dlinford@purdue.edu
}

JASON MEGILL

Department of Philosophy, Bentley University, Waltham, MA 02452, USA

e-mail: jmegill@bentley.edu

\begin{abstract}
We utilize contemporary cognitive and social science of religion to defend a controversial thesis: the human cognitive apparatus gratuitously inclines humans to religious activity oriented around entities other than the God of classical theism. Using this thesis, we update and defend two arguments drawn from David Hume: (i) the argument from idolatry, which argues that the God of classical theism does not exist, and (ii) the argument from indifference, which argues that if the God of classical theism exists, God is indifferent to our religious activity.
\end{abstract}

\section{Introduction}

Let's say that idolatry is religious activity centred on a real or imagined entity other than the God of classical theism. ${ }^{1}$ While idolatry has often been discussed as an accusation lodged by one religion against another, we introduce, develop, and defend two irreligious arguments, originating with David Hume, utilizing idolatry, which we call the 'argument from idolatry' and the 'argument from indifference'. Both suppose that if God desired for humans not to be idolatrous, the human cognitive apparatus would not gratuitously incline humans to idolatry. The two arguments differ on whether classical theism entails that God desires for us not to be idolatrous. The argument from idolatry supposes the god of classical theism would desire for us to avoid idolatry; in that case, our gratuitous natural inclination to idolatry entails that no such god exists. In contrast, according to the argument from indifference, classical theism does not entail that God would 
desire for us to avoid idolatry; the argument concludes that God does not care whether we avoid idolatry.

In the next two sections, we offer the arguments from idolatry and indifference. Then, we begin our discussion of Hume's psychology of religion and relate Hume's theory of action to two general categories of religious activity: superstition and enthusiasm. The following section offers an interpretation of superstition, while updating and vindicating Hume's account with work in the social scientific study of religion. Likewise, the subsequent section offers an interpretation of enthusiasm and, again, updates Hume's account. We reinterpret superstition and enthusiasm as two widespread, significant, natural tendencies (a superstitious tendency and an enthusiastic tendency) and suggest that both produce (or are) gratuitous inclinations to idolatry.

\section{The argument from idolatry}

The elements comprising the arguments from idolatry and from indifference are scattered throughout Hume's corpus. We do not claim either argument is explicitly offered in any particular text. Nonetheless, the two arguments have a distinctly Humean flavour; previous authors have identified similar themes (Siebert (1984); Holden (2010); De Cruz (2015)). Some of Hume's discussion of religion (e.g. in his Natural History of Religion and 'Of Superstition and Enthusiasm') resembles early modern authors engaged in internecine religious conflicts (e.g. Pocock (1997)). But, unlike his orthodox contemporaries, Hume leaves little room for non-idolatrous religion. This is for good reason: for Hume, non-idolatrous religion was not possible. Two possible consequences can be drawn: either God does not exist (the argument from idolatry) or is indifferent to our religious activity (the argument from indifference). We begin with the argument from idolatry:

(1) If the God of classical theism exists, then God wants us to avoid idolatry.

(2) If God wants us to avoid idolatry, then our cognitive apparatus does not gratuitously incline us to idolatry.

(3) Our cognitive apparatus gratuitously inclines us to idolatry.

(4) So, God does not want us to avoid idolatry (modus tollens from 2 and 3 ).

(5) Therefore, the God of classical theism does not exist (modus tollens from 1 and 4).

Premise (3) is our most controversial and will again be utilized in the argument from indifference. Therefore, we spend most of this article defending (3). Likewise, as we will describe, Hume devoted his attention to (3). While we provide a more 
complete discussion of Hume's psychology of religion in subsequent sections, we briefly summarize the argument here.

Hume argued that actions originate from a combination of passions, sensations, and ideas ( $\mathrm{T}$ 2.3.3; 3.1.1). Ideas and sensations are motivationally inert, but determine the conditions under which our passions arise. In turn, ideas aid our evaluations of how to deliver on our ends, as provided by our passions. So, to have actions motivated towards God, one must have an impression or an idea of God. God is 'no object of the senses or the imagination, and very little of the understanding'. Moreover, God is infinitely remote and incomprehensible; one may 'feel no Affection towards him' (WC). We conceive of God as remote due to a combination of cognitive and cultural dispositions. Though psychologically disposed to religion, humans elevate their deities until their deities can no longer generate passions. Finally, humans reorient their religious activity around non-transcendent entities (NHR, especially section VIII). Thus, human psychology inclines people to idolatry because their psychology inclines them to worship real or imagined entities importantly unlike God. Having summarized the argument for (3) which we will momentarily return to in section IV - something needs to be said with respect to (1) and (2). Hume does not devote much time to defending either, so we embark on a long digression.

While traditional theology has defended (1) in a variety of ways, ${ }^{2}$ the most convincing argument for (1) appeals to the nature of love. We pump the relevant intuitions through a thought experiment. Suppose Pam tells us that Roy loves her. Subsequently, we learn:

(i) Roy avoids Pam.

(ii) Pam spends her time with Jim, whom she thinks is Roy.

(iii) Roy knows Pam thinks Jim is Roy.

(iv) Roy has expended effort in strengthening Pam's belief that Jim is Roy.

From (i)-(iv), we should infer that, ceteris paribus, Pam is mistaken about Roy's feelings. Likewise, if God loves us, ceteris paribus, God would prefer for us to engage God instead of surrogates in our religious activity and God would not cause us to be disposed to mistake surrogates for God.

One reason (i)-(iv) are incompatible with Roy loving Pam is that Roy has deceived Pam so that she is unable to respond appropriately to Jim or Roy. Likewise, idolaters are unable to respond appropriately to God. Through relationship with God, we could come to learn the Good and lead lives through God's teachings. To grow in relationship with God could involve moral maturation. Those who have a mistaken view of who God is, what God desires for us, and who are disabled from moral maturation can wreak incredible moral evil. (Note that the appeal to moral error does not necessarily suggest a version of the problem of evil. Here, our claim is that, ceteris paribus, God desires that we 
avoid moral error and that we strive towards moral maturity. This may be so even if moral error is consistent with God's goodness.)

Perhaps these reasons for accepting (1) - or the others we list in footnote 2 - are not convincing, and perhaps no other convincing reasons can be provided. We will consider the consequences of rejecting (1) when we turn to the argument from indifference. For now, suppose (1) is true. Let's turn to (2) (if God wants us to avoid idolatry, then our cognitive apparatus does not gratuitously incline us to idolatry). Here, we've modified Hume's view and added the notion of a gratuitous inclination. Whereas Hume believed that religious activity oriented around the classical theistic God is not possible, we maintain the weaker thesis that religious activity oriented around God is more difficult (in a sense to be specified) than expected on classical theism.

God may have countervailing desires overriding God's desire for us to avoid idolatry and may therefore allow some inclination to idolatry. For example, God may recognize our free will as a great good. In order to allow us to have freewill, God might have created us with fallible access to theological truths, and that fallible access may incline some to idolatry. Those who love do not coerce the beloved into relationship (or, if they do, this is a flaw in the way that they love; God lacks flaws, so would not coerce us). Likewise, we find it plausible that, ceteris paribus, God would not coerce us into mistaking other entities (real or imagined) for God. Consider again our thought experiment concerning Pam. Suppose that one evening, while Pam is sleeping, Roy performs brain surgery on Pam, so that Pam will be much more inclined to mistake Jim for Roy than she would otherwise be. This would be yet stronger evidence that Roy does not love Pam; Roy would have produced in Pam a gratuitous inclination to mistake Jim for Roy. ${ }^{3}$

A gratuitous inclination to idolatry is an inclination fulfilling at least one of two conditions. An agent A is gratuitously inclined to idolatry if:

(v) due to A's cognitive (and possibly social or economic) situation C, A is more inclined to idolatry than is necessary for the attainment of some overriding divine purpose or

(vi) in the case that God exists and created A, God would antecedently know that if God created A such that C differed, the world would certainly or probably be a better fit for God's purposes than the world would otherwise be.

Here, we've adapted Kraay (2016)'s discussion of gratuitous evil in order to develop our notion of a gratuitous inclination to idolatry. ${ }^{4}$ Nonetheless, gratuitous inclinations to idolatry need not be gratuitous evils and our argument should not be understood as an instance of an evidential argument from evil. This is so for two reasons. First, God's purposes in allowing or disallowing the degree to which A is inclined to idolatry may not involve moral considerations and so may not involve 
considerations about goods or evils at all. The argument from idolatry might simply involve considerations about, for example, God's love. ${ }^{5}$ Or consider van Inwagen (2002), where van Inwagen considers possible worlds where (a) there are horrendous evils but God's presence is known to all who are non-resistant and (b) there are no horrendous evils but there are non-resistant non-believers. ${ }^{6}$ If van Inwagen is right, it's hard to see why we couldn't similarly imagine worlds where there are $\left(\mathrm{a}^{*}\right)$ gratuitous evils but no gratuitous inclination to idolatry and $\left(b^{*}\right)$ no gratuitous evils but there is gratuitous inclination to idolatry. If such worlds are conceptually possible, then the gratuitous inclination to idolatry is not necessarily an instance of gratuitous evil, and the incompatibility between classical theism and gratuitous idolatry is not a concern about God's distinctively moral properties. Second, although idolatry may be bad for a variety of reasons (as surveyed in note 2), it is unclear whether an inclination to some bad activity is itself bad; it is also unclear whether the badness is gratuitous whenever the inclination is gratuitous.

Insofar as God is instrumentally rational, God's design and providence should reflect God's will. Therefore, while there may be some tendency to idolatry even in the case that God desires for us not to be idolatrous, the idolatry would not be gratuitous. In this article, like Hume, we've focused on how people are contingently cognitively arranged. ${ }^{7}$ Given other cognitive arrangements, humans would have been less inclined to idolatry than they are, and, according to the argument from idolatry, this is reason to think the classical theistic God does not exist.

\section{The argument from indifference}

As discussed previously, God might not desire for us to avoid idolatry; perhaps (1) is false. Supposing (1) is false, (2) and (3) can be used to construct the argument from indifference:

(2) If God wants us to avoid idolatry, then our cognitive apparatus does not gratuitously incline us to idolatry.

(3) Our cognitive apparatus gratuitously inclines us to idolatry.

(4) Therefore, God does not want us to avoid idolatry.

Serious theological implications follow from (4). Suppose classical theism is true. The God of classical theism is perfectly good and perfectly loving. If a perfectly loving being would not want us to avoid idolatry, the concept of perfect love must not entail that one would not incline one's beloved to mistake others for oneself. We've apparently gone wrong in how we've conceived of loving relationships.

Moreover, as a perfectly good and loving being, ceteris paribus, God would desire for Her creatures to experience good lives. So, if having theologically correct beliefs offered some unique route to important goods, ceteris paribus, 
God would desire for us to have theologically correct beliefs. If God does not desire for us to avoid idolatry, then God does not desire for us to have theologically correct beliefs; by implication, having theologically correct beliefs does not offer some unique route to important goods. Contrary to doctrines found in Christianity, Islam, and Judaism, theologically correct beliefs would not be a unique route to, e.g., salvation, afterlife in God's presence, a meaningful, purposeful, or ethical life, and so on (Megill \& Linford (2017)).

Remember Pam, Jim, and Roy. One reason Roy's deception was taken to be incompatible with Roy's love was that Pam would have been disabled from responding appropriately to Roy. This example seemed to suggest idolatry inhibits proper relationship with God, inhibiting moral growth. But if a gratuitous inclination to idolatry does not inhibit moral growth, as suggested if God is indifferent to theological correctness, then moral growth is available regardless of one's religious beliefs. The argument from indifference may provide new grounds for religious pluralism; if having theologically correct beliefs is not a unique route to important goods, then membership in any particular religion is not important for obtaining those goods.

\section{Hume and our inclination to idolatry}

Our arguments from idolatry and from indifference are intended as further developments of arguments originating with Hume's psychology of religion. For the remainder of our article, we turn to explicating Hume's defence of (3) - that our cognitive apparatus inclines us to idolatry - and updating Hume's defence in light of the contemporary social scientific study of religion. Hume discusses two 'corruptions of true religion', 'superstition' and 'enthusiasm', resulting from our cognitive inability to hold God as a proper object of the passions (SE 75). We are thereby inclined to idolatry. Hume left little room for other kinds of religious activity. While Hume's Natural History of Religion traces religion's 'origin in human nature' (NHR Intro.1), the focus is on an anthropology and history of religion. Hume's psychology of religion, especially its connection to Hume's theory of human action, needs to be constructed from what Hume says elsewhere. For Hume, only the passions (and not reason) motivate action ( $\mathrm{T} 2.3 .3$; 3.1.1); therefore, to interpret Hume's psychology of religion, we need to examine those passions to which Hume attributed religious activity. The theme throughout is that there is no passion whose object is a transcendent God.

Hume's 1743 letter to William Mure of Caldwell (WC) is crucial for understanding the relationship between Hume's action theory and account of religion. For Hume, our emotions are more aroused by someone closer than by someone further away. For example, we feel more sympathy for a neighbour than for a distant stranger ( $\mathrm{T}$ 2.3.7; 3.2.1). A remote and distant ancestor who left us 'Estates \& Honours, acquired with Virtue' might be a 'great Benefactor', but we cannot possibly 'bear him any Affection' due to his remoteness. We have never 
encountered, through sense experience, anything like God. Neither the 'Passions' nor the 'calm Affections' can operate 'without the Assistance of the Senses, \& Imagination, or at least a more complete Knowledge of the Object than we have of the Deity'. God is an infinite, incomprehensible being, radically beyond the finite experience or cognitive abilities of human beings; God cannot be 'the natural Object of any Passion or Affection', because God is not an object of the 'Senses or Imagination', and enters 'very little of the Understanding'. Therefore, a fortiori, our passions cannot be aroused by God (WC). ${ }^{8}$ Because a remote, incomprehensible God cannot be the object of religious activity, Hume argues that religious activity can originate in two ways: either religious individuals invent subordinate beings who can be the objects of religious activity (as in superstition) or the object of religious activity is the self (as in enthusiasm). We discuss these in turn.

\section{Superstition}

For Hume, superstitious religion is a response to an internal theological tension. The Abrahamic religions teach that religious activity should be oriented around a radically transcendent God. Simultaneously, the greater God's transcendence, the less God can be an object for the passions. Superstitions are 'false religions' originating in weakness, fear, melancholy, and ignorance, and are immoral (SE 75). ${ }^{9}$ Of these, only fear and melancholy (despair) are passions. ${ }^{10}$ As Cohon interprets, the objects of direct passions - of which fear and melancholy are examples - is the pleasure or pain we may experience (Cohon (2011), 171). ${ }^{11}$ Due to our weakness, the world can harm us in innumerable ways. Due to our ignorance, we postulate and fear powerful, unseen invisible agents responsible for various harms, real and imagined. To avoid experiencing harm, the superstitious develop methods to appease the unseen forces; these unseen forces can explain the natural phenomena that might do harm to us (SE 75; NHR III.1). To placate the unseen agents, the unseen agents are praised and through praise elevated until they vastly exceed the cognitive abilities of human beings. The many unseen agents become a singular being of the 'utmost bounds of perfection' (NHR VIII.2), whose properties - e.g. unity, simplicity - are categorically distinct from anything in the material realm.

A radically elevated conception of God is unstable and unfit for 'vulgar comprehension'. In order to orient religious activity around the incomprehensible, new subordinate entities (angels, demigods, demons, saints, etc.) were introduced (NHR VIII.2); but the subordinate entities are idols. Alternatively, some religions slide into worshipping artwork. This explains doctrinal prohibitions on artwork. ${ }^{12}$ And so our cognitive architecture leads practitioners to replace a remote, transcendent God with more immediately accessible surrogates. 


\section{The empirical evidence}

We defend three claims crucial for Hume's account of superstition: (i) religious belief frequently originates with existential fears, (ii) humans have cognitive limitations in conceiving of a transcendent being, and (iii) due to our cognitive limitations, humans tend towards idolatry. We turn first to the empirical evidence for claims (ii) and (iii); afterwards, we turn to (i). We do not follow Hume in identifying specific religions as monolithically superstitious. Instead, we maintain that the phenomenon Hume identifies as superstition is a significant, widespread, and natural psychological tendency, which may be found across a variety of religions, and that gratuitously inclines the folk to idolatry.

For all we say here, careful academic theological study may aid people in reasoning about God and so reduce the degree to which they are inclined to idolatry. However, most theists have not undergone careful theological study and most do not have the time or resources to do so. We are specifically interested in the religious beliefs cognitively or contextually available for the folk. We can distinguish two contexts of reasoning: theoretical reasoning - as employed in academic theology - and the application of reason to concrete instances in ordinary life which we will call 'practical reasoning'. Scientists studying religion now generally accept, 'as an empirically established fact', that the folk use anthropomorphic God concepts, differing from 'theologically correct' conceptions, in practical reasoning (Westh (2014) ). ${ }^{13}$ Helen de Cruz has previously written on the relevance of Hume to the scientific study of religion. As she describes, Hume was right to think theological correctness is difficult to maintain. And yet folk religious beliefs are 'easy to acquire' (de Cruz (2015), 6). The result is what Pascal Boyer terms the 'tragedy of the theologian' (Boyer (2001), 283-285). ${ }^{14}$ Theologians might attempt to maintain official doctrines, but their work does not provide substance to which religiously oriented passions coincide. Social scientists report that the folk endorse a kind of 'folk religion', constructed in the gap between the pulpit and the pew, and that exists 'apart from and along-side the strictly theological and liturgical forms of the official religion' (Yoder (1974), 14).

Among the most cognitively appealing beliefs, common in folk religions across cultures, are those which involve anthropomorphic supernatural agents, such as angels, protector spirits, or otherwise non-transcendent divine entities, who intervene in otherwise threatening situations. For example, in the United States, widespread belief in, and reports of visitation by, angels transcends institutional religious boundaries and is found among those who have rejected traditional religions in favour of New Age practices (Draper \& Baker (2011)). The cognitive appeal of such agents makes 'such beliefs likely to be adopted, as they are "immediately relevant for human concerns"' (ibid., 627).

Similarly, the folk are inclined to an anthropomorphic conception of God, especially in the context of cognitive load, even when they abstractly endorse classical theism. According to cognitive scientists Barrett and Keil (1996), the folk reason inconsistently about the divine between abstract and practical reasoning. 
Abstractly, the folk often say God possesses transcendent properties as described by their theological traditions (including those properties included in classical theism). ${ }^{15}$ Barrett and Keil found unanimous agreement among twenty-two undergraduate and graduate students that 'God can read minds, knows everything, can perform multiple mental activities at the same time, does not need to be near something to receive sensory information about it, and has non-natural spatial properties' (ibid., 228). To examine how the students cognized God in a practical context, and under conditions of cognitive load, they were provided with a narrative recall task. ${ }^{16}$ In the task, the subjects were read short vignettes concerning God's involvement in particular situations. The vignettes are too long to commit completely to memory. Subjects were later asked to recall the vignette. Differences between the original vignette and the recalled vignette reveal how subjects processed the vignettes and committed them to memory. For example, one vignette concerns God answering two prayers, one the prayer of a boy caught in a river (ibid., 229-230). The story does not indicate whether God answered the other prayer before the boy's prayer. Someone who conceives of God anthropomorphically might say God finished answering the first prayer before attending to the boy. Someone who consistently reasons about God in non-anthropomorphic terms - as without limitations - may say God helped the boy while simultaneously attending to the first prayer. When asked to explain the vignette, subjects typically indicated that God answered one prayer at a time.

In explaining other vignettes, subjects utilized an anthropomorphic conception of God at odds with their theological traditions (and at odds with classical theism). God is conceived as a special 'Big Person': 'there was a strong tendency for subjects to think of God [as] exhibiting human limitations' (ibid.). Barrett and Keil summarize:

\footnotetext{
subjects seemed to characterize God as having to be near something to receive sensory information from it, not being able to attend differentially to competing sensory stimuli, performing tasks sequentially and not in parallel, having a single or limited focus of attention, moving from place to place, and sometimes standing or walking. (ibid., 229-230)
}

Later work reproduced the effect among Hindu and Muslim participants, from India, with diverse gender, educational, and economic categories (Barrett (1998) ).

While Barrett and Keil have their critics, the critics agree that anthropomorphism is a common feature of religion. Moreover, theological incorrectness can take forms other than anthropomorphism. For example, (Westh (2014)) provides cross-cultural examples supporting Hume's psychology of religion, in that the folk either anthropomorphize God or conceptualize God in mundane, earthly terms. The Maasai, for instance, 'represent their god EnkAi in radically different ways in different contexts' (ibid., 409). Mythically, EnkAi is 'fully anthropomorphic, even living among men in primeval times'. As Westh goes on to explain, 'in traditional hymns of prayer, [EnkAi] is identified variously with the sky, the earth and with other elements of nature' (ibid.; also see Olsson (1999), 83). While the 
Maasai's traditional hymns differ from the mythical representation, in that the hymns do not anthropomorphize God, they still identify EnkAi with mundane experiences in common life (the sky, earth, and 'other elements of nature'). Westh appeals to Olsson's ethnography to conclude that when the Maasai turn to serious theological reflection, neither mythical nor hymnal representations 'are considered to be literally true' (Westh (2014), 410). Olsson explains that 'the Maasai conclude from myth ... that primeval man somehow had a direct experience of God and from this knew his nature, but what this experience really meant is not known any more'. Consequently, 'no human being . . . can know what God used to be like' (Olsson (1999), 79).

Similarly, the Babylonian god Girra was ritualistically identified with fire, but understood to be anthropomorphic in 'narrative texts' (Westh (2014), 410). While non-anthropomorphic, fire does not transcend common life, so the identification is consistent with Hume. '[I]n the context of the official [Babylonian/ Assyrian] temple cult most gods lived in their temples, where they received daily food offerings, while in other contexts they were represented as immanent in natural phenomena, or as anthropomorphic beings living in heaven' (ibid.). Similar conclusions can be reached for ancient Egyptian, Abrahamic religions, and the ancient Greeks (Olsson (1999), 87-91).

Further instances of religion oriented around this-worldly items can be offered and compared to Hume. For Atran and Sperber, supernatural entities need to be related to mundane experience for belief retention and cultural transmission; religious beliefs are predictably counter-intuitive, but only in specific and minimal ways. ${ }^{17}$ Minimally counter-intuitive beliefs about $x$ depict $x$ as violating only a few expectations given by the ontological category in which $x$ appears (Boyer (2001), 64-65). Importantly, 'only to the degree that the [minimally counter-intuitive concepts] remain bridged to the everyday world can information be stored and evoked in plausible grades' (Atran \& Sperber (1991), 52). Justice and Lambert (1986) and Birky and Ball (1988) suggest that people's conceptions of God are partly determined by the personalities of their parents. Barrett and Van Orman (1996) suggest that those who use images of God in worship anthropomorphize God to a greater degree than those who do not. Many more examples could be given (Guthrie (1980) ). Theologians have sometimes maintained a similar point, e.g. Marcus Borg's discussion of fathers as improper (patriarchal) models of God and then parents as appropriate models of God (Borg (1997), 64-71, 73).

\section{Fear and the social scientific study of religion}

We've established that humans have cognitive limitations in conceiving of a transcendent being (claim ii) and that due to those limitations, humans tend towards idolatry (claim iii). We turn to addressing claim (i): frequently, religious belief originates with existential fears. For Hume, superstition originates with existential fears in a dangerous and uncertain world. Because of those fears, humans 
elevate the initial objects of their religious activity beyond their cognitive capacities. At that point, humans turn to surrogates. Intuitively, we think love of God is an appropriate motivation for devotion to and worship of God. For Hume, love of God cannot motivate religious activity. The object of love of God is God, but Hume thought no passion could have God as the object. Fear provides an alternative to love of God as a motivation for devotional and worshipful activity. Recall the argument from our conception of love for the view that God would not gratuitously incline us to idolatry. If Roy loves Pam, then Roy desires that Pam is motivated to relationship with Roy out of love and not out of fear. A fortiori, if we learn Roy rewired Pam's brain so that Pam is more disposed than she would otherwise be to enter relationship with Roy out of fear as opposed to love, we have reason to think Roy does not love Pam. On our modified Humean account, while we allow for the possibility that some people love God, a gratuitous disposition to enter relationship with God out of fear is incompatible with classical theism, and this is doubly so if the disposition to relate inappropriately to God results in theologically incorrect beliefs.

The social scientific study of religion has long associated fear (or, more generally, anxiety) with religious belief. As Hume thought, people fear the harms that powerful, unseen forces might do to them; people fear most that they will be killed. To cope with their anxieties around death, many cultures have constructed elaborate systems of rituals and venerations to appease powerful, unseen forces, or to ensure their passage into an afterlife. ${ }^{18}$ As we argue in this section, devotional and worshipful activity is often motivated by fear and oriented around accessible, anthropomorphic conceptions of the divine.

Morton-Williams's comments on Yoruba religion are helpful in illustrating some implications of Hume's psychology of religion. Yoruba cosmology divides the world into three realms: Earth, Sky, and ile aiye, the house of the World, which we inhabit. Earth and Sky are populated by unseen, powerful forces the Yoruba either work with or against. Morton-Williams writes: 'Life in the third cosmic realm, ila aiye ..., is good only when good relationships are maintained with the gods and spirits of the other two' (Morton-Williams (1964), 246). Elsewhere, Morton-Williams describes the Yoruba as 'constantly on guard against [death]'. The Yoruba 'make sacrifices to the gods to gain their protection and avoid their wrath'. While the Yoruba endorse several hundred gods, individuals worship the few 'concerned with him' and 'proper to [their] lineage'. Other deities are sometimes addressed in response to other anxieties: 'The gods not only shield their worshippers, they also give them the blessings Yoruba most value: long life, increasing prosperity, and, above all, children' (Morton-Williams (1960), 34-35). The Yoruba acknowledge a hierarchy of gods, overseen by the transcendent creator deity Olurun (literally 'Sky-Owner', translated by Morton-Williams as 'God'). Yet Olurun has no cult on Earth, because - as Hume predicts - religious activity is primarily focused on interactions with the subordinate deities (ibid., 40). 
Consistent with Hume's account, Yoruba religious activity is typically motivated by anxieties associated with the lesser deities. The lesser deities can be unjust or vengeful, but can be sated or placated through rituals or tattoos. If one finds favour with the minor deities, the deities can provide the 'blessing of children, health, and, if their God-ordained fate permits it, wealth' (Morton-Williams (1964), 246). The gods can be predictable and 'the terrified apprehension of death . . . is eased by carefully watching for signs of their demands' (MortonWilliams (1960), 35). Death is explained in a variety of ways, each involving powerful, unseen entities. Witchcraft explains the death of newborns ('The Yoruba admit that they fear witchcraft more than anything else'). Sango, the god of thunder, causes lightning strikes. Sopona delivers small-pox epidemics (ibid.).

Contemporary cognitive science of religion similarly links anxiety or fear of death to religious belief. We offer some representative studies. ${ }^{19}$ Harding et al. (2005) used standard psychological instruments to measure death anxiety, death acceptance, and religiosity (together with relevant controls) among 130 individuals from an Episcopalian church in New York City. Death anxiety and death acceptance were negatively correlated; subjects who reported more anxiety about death also reported that they were less accepting of the inevitability of death. Belief in God, the afterlife, and gender were the only variables that explained the variance in the death anxiety scores; only belief in God and the afterlife predicted the death acceptance scores (ibid., 256). People who reported more certainty about God's existence reported less anxiety and more acceptance of death. ${ }^{20}$

Harding et al. did not record longitudinal data and cannot be used to establish conclusively that religious belief lowers death anxiety and increases death acceptance, or that pre-existent death anxiety brings about heightened religious belief. Nonetheless, the correlation identified by Harding et al. provides some evidence that religious belief lowers anxiety, at least for those who already believe. Plausibly, anxious individuals pursue activities they have found to be useful in the past for relieving anxiety or which they have observed to be useful for others. Therefore, theists who are anxious about death might be motivated to pursue a deeper commitment to their faith. Some communities might make use of the effect. Whitehouse (1996) provides ethnographic data suggesting Melanesian initiation cults put their initiates through terrifying rituals ('Rites of Terror') after which the initiates have a greater commitment to the group.

Norenzayan and Hansen (2006) performed four experiments providing evidence that fear of death motivates religious activity. According to Terror Management Theory (TMT), 'cultural worldviews, along with the desire to live up to the standards of one's culture (i.e., self-esteem), serve as a primary psychological buffer against the uniquely human awareness of death. If so, heightening such terror (mortality salience) should increase the need to bolster these worldviews' (ibid., 175). TMT predicts that subjects who have religious beliefs will report greater commitment to those beliefs if exposed to a mortality salience stimulus, and will simultaneously report a stronger rejection of foreign religious notions. However, 
according to other theorists (and, for our purposes, Hume in particular), subjects who are primed to think about death will report a strengthened commitment to the existence of supernatural agents in general and will thus be more open to culturally foreign supernatural agents. The four experiments can be used to distinguish empirically between TMT and Hume's account, even though Norenzayan and Hansen do not utilize their experiments for that purpose.

The first two experiments were consistent with both TMT and Hume, while the latter two support Hume over TMT. In the first experiment, subjects reported a statistically higher commitment both to their personal religion and to their belief in God, as compared to a control group, when primed to think about death. In the second experiment, subjects who were exposed to a mortality salience stimulus explained an unusual phenomenon (the efficacy of prayer) with general affirmation of God's existence and specific affirmation of God's role in the phenomenon (God answers prayers). Subjects were more likely to report a theistic explanation for the efficacy of prayer after having been primed to think about death than they were when primed to think about religion (ibid., 178-179).

Experiments three and four repeated experiment two, but replaced God with culturally foreign supernatural agents: in experiment three, Buddha and, in experiment four, supernatural agents that do not belong to any world religion ('ancestral Shamanic spirits'; ibid., 180-183). The results were consistent with Hume but inconsistent with TMT: mortality salience stimulus increases the propensity to accept supernatural agents generally-even culturally foreign supernatural agents - for individuals with a pre-existing proclivity to religious belief. Fear of death motivated religious belief and not, as one might think, love of God. The result is a gratuitous inclination to idolatry, in part, comprised by theologically inappropriate reasons for relating to God and theologically incorrect beliefs.

\section{Enthusiasm}

Superstition is not the only form of idolatry that Hume discusses. Like superstition, enthusiasm involves passions for which the object is something other than the radically transcendent God. According to Pocock, 'The Greek enthousiasmos carries the Latinate meanings of infusion and inspiration: the inpouring or in-breathing of the divine, which comes to inhabit the person possessed' (Pocock (1997), 9). In Christian theology, one may experience the indwelling of the Holy Spirit; thereby, one might be (figuratively) infused with the divine. Most early modern authors reserved 'enthusiasm' for radical protestant sects for whom the (supposed) experience of the Holy Spirit was deemed politically disruptive (ibid., 10). On Hume's account, 'enthusiasm' came to be identified with a more general social or psychological phenomenon for explaining tendencies in Protestant churches.

For Hume, positive emotions - such as personal success, health, confidence, boldness, and elation (Yandell (1990), 281-282) - can result in what Pocock 
describes as the 'self-deification of the auto-intoxicated mind' (Pocock (1997), 22). As Hume describes, the mind can be 'subject to' an elevation and a presumption 'arising from prosperous spirits, luxurious health, strong spirits,' or a 'bold and confident disposition'. Hume remarks the 'imagination swells with great, but confused conceptions, to which no sublunary beauties or enjoyments can correspond' (SE 75). ${ }^{21}$ One turns away from the Earthly realm, partaking in 'raptures', 'transports', and 'surprising flights of fancy'. Since these feelings go beyond what the enthusiast understands as mundane sensations, they are attributed to God ('who [they think] is the object of devotion'; SE 75). In the process, one comes to see oneself as the special creation of God. Thereby, one becomes prideful.

Hume's account of enthusiasm begins with the observation of 'external [social] events', e.g. 'prosperous success', 'luxuriant health', but also 'strong spirits' and a 'bold and confident disposition' (Immerwahr (1996), 327-328). Enthusiasm is associated with hope, pride, presumption, 'warm imagination', and ignorance. Of these, hope and pride are the only passions. Hope is a direct passion while pride is an indirect passion. The object of hope is the pleasure we may have from the thing hoped for (Cohon (2011), 167). The object of pride is the self (or perhaps an object related to the self, e.g. one's child or a friend). For Hume, the locution 'self-love' is confused; one cannot truly love the self, but one can be prideful. Pride and love follow from a coupling of ideas and sensations. Love follows from a pleasant sensation coupled with the idea of another person. Pride follows from a pleasant sensation coupled with the self ( $T$ 2.2.1.2; 2.2.1.3). Instead of worshiping a statue, a relic, or a lesser deity, enthusiasts are motivated by pride to self-worship. ${ }^{22}$ Enthusiastic religion, then, is developed through a general ignorance of our emotions and the source of our successes, and through the influence of hope, pride, confidence, and anthropomorphism.

\section{The empirical evidence}

As with superstition, we do not follow Hume in his thought that specific religions are monolithically enthusiastic. Instead, we understand the phenomenon Hume identifies as enthusiasm as a widespread, significant, and general psychological tendency (or disposition) gratuitously inclining people to idolatry. The theological and popular religious literatures frequently claim that self-worship results from a common variety of religious error. Religious authors have argued that apostates chose to worship themselves in place of God (Plantinga (2000), 208; MacArthur (2005), 192) or that secular society is morally degraded because people have placed themselves before God. (For a particularly vivid example of the latter, see Scalia (2013), ch. 2.) Religious scriptures are replete with prohibitions against self-worship and with instructions to abdicate oneself before God.

Could the common prohibition against prideful self-worship be a consequence of the ease with which religious individuals slip into prideful self-worship? Communities infrequently prohibit actions that do not occur among their 
members. ${ }^{23}$ The common occurrence of prohibitions against prideful self-worship suggests that members of religious communities easily slip into self-worship in acts of religious veneration. When interviewed, sociologists found that some Christians attribute to atheists a self-interested egoism into which the Christians fear the Christians might slip if they lost their faith (Edgell et al. (2006), 227-228). Psychologists have shown that self-esteem correlates with one's conception of God. Benson and Spilka (1973) studied 128 Catholics; those with high self-esteem tended to posit a loving and accepting God. As Hume writes, one's 'bold and confident disposition' may play a causal role in explaining one's conception of God. Perhaps the object of the emotions inclining some to religious activity is the self. And if all that is right, many are gratuitously inclined to idolatry.

\section{Conclusion}

Hume discusses two forms of idolatry (superstition and enthusiasm) generating the arguments from idolatry and indifference. Both result from our cognitive inability for God to be the object of our passions. Only passions can motivate, so religious activity must originate elsewhere than God. The superstitious worship non-transcendent, anthropomorphic entities because a transcendent being far exceeds our cognitive abilities. The enthusiasts worship themselves in disguise. Some are moved to religious activity by fear, whose object is pain, and others worship idols or their passions are stirred by the self. Fear and pride are inappropriate motivations for religious activity and result in idolatry.

There are reasons to reject aspects of Hume's psychology, epistemology, action theory, his taxonomy of emotions (or passions), claims made about particular religions, and so on. But if superstition and enthusiasm are reinterpreted as two widespread, significant, general tendencies gratuitously inclining people to idolatry, core Humean claims are supported by empirical work in the scientific study of religion; these core claims allowed us to construct the arguments from idolatry and indifference. First, due to their psychologies, the folk hold crude God concepts falling far short of classical theism. Much religion is oriented around either lesser divine beings or crude anthropomorphisms. Second, Hume suggests humans are cognitively wired for idolatry. We endorse a weaker version of this claim: for all we know, some humans avoid idolatry, but humans have a gratuitous inclination to idolatry explained by their cognitive architecture. Third, the human inclination to idolatry is partly explained by our fears and prides, motivations inappropriate for devotional and worshipful behaviour. Our disposition to such behaviour is contrary to intuitive notions of love, either suggesting that no loving God exists or that our conception of love requires radical revision. 


\section{References}

\section{Works by Hume are cited as:}

$\mathrm{HE}=$

The History of England. Page numbers correspond to vol. IV of the 1826 edition (Oxford: Talboys \& Wheckler).

$\mathrm{NHR}=$

The Natural History of Religion. Quotations are taken from the 1889 edition with an Introduction by John M. Robertson (London: A. \& H. Bradlaugh Bonner). $\mathrm{SE}=$

'Superstition and enthusiasm', in Eugene Miller (ed.) David Hume, Essays: Moral, Political, and Literary (Indianapolis: Liberty Fund, 1987), 73-79.

$\mathrm{T}=$

A Treatise of Human Nature, ed. L. A. Selby-Bigge, 2nd edn with text revised and variant readings by P. H. Nidditch (Oxford: Clarendon Press, 1978 [1738]).

$\mathrm{WC}=$

'To William Caldwell (1743)', in Antony Flew (ed.) David Hume: Writings on Religion

(LaSalle IL: Open Court, 1992), 17-20.

Atran, Sсотт (2002) In Gods We Trust: The Evolutionary Landscape of Religion (Oxford: Oxford University Press). Atran, Scott \& Sperber, Dan (1991) 'Learning without teaching: its place in culture', in Liliana Tolchinsky Landsmann (ed.) Culture, Schooling, and Psychological Development (Norwood NJ: Ablex Publishing Corporation), 39-55.

Argyle, Michael \& Beit-Hallahmi, Benjamin (1997) The Psychology of Religious Behavior, Belief and Experience (London: Routledge).

Barrett, Justin (1998) 'Cognitive constraints on Hindu concepts of the divine', Journal for the Scientific Study of Religion, 37, 608-619.

BARRETT, Justin (1999) 'Theological correctness: cognitive constraint and the study of religion', Method and Theory in the Study of Religion, 11, 325-339.

Barrett, Justin (2011) Cognitive Science, Religion, and Theology: From Human Minds to Divine Minds (West Conshohocken PA: Templeton Press).

Barrett, Justin \& Keil, Frank (1996) 'Conceptualizing a nonnatural entity: anthropomorphism in God concepts', Cognitive Psychology, 31, 219-247.

Barrett, Justin \& VAN Orman, Brant (1996) 'The effects of the use of images in worship on God concepts', Journal of Psychology and Christianity, 15, 38-45.

Benson, Peter \& Spilka, Bernard (1973) 'God image as a function of self-esteem and locus of control', Journal for the Scientific Study of Religion, 12, 297-310.

Birky, Ian \& Ball, Samuel (1988) 'Parental trait influence on God as an object representation', Journal of Psychology, 122, 133-137.

Borg, Marcus (1997) The God We Never Knew: Beyond Dogmatic Religion to a More Authentic Contemporary Faith (San Francisco: HarperOne).

BOYER, PASCAL (2001) Religion Explained: The Evolutionary Origins of Religious Thought (New York: Basic Books).

Clark, Kelly (2010) 'Reformed epistemology and the cognitive science of religion', in Melville Stewart (ed.) Science and Religion in Dialogue, I (Hoboken NJ: Wiley-Blackwell), 500-513.

Clark, Kelly \& Barrett, Justin (2010) 'Reformed epistemology and the cognitive science of religion', Faith and Philosophy, 27, 174-189.

Clark, KelLy \& Barrett, Justin (2011) 'Reidian religious epistemology and the cognitive science of religion', Journal of the American Academy of Religion, 79, 639-675.

СоHоN, Rachel (2011) 'Hume's indirect passions', in Elizabeth Radcliffe (ed.) A Companion to Hume (Malden MA: John Wiley \& Sons, Inc.), 159-184.

De Cruz, Helen (2013) 'Cognitive science of religion and the study of theological concepts', Topoi, 33, 487-497.

De Cruz, Helen (2015) ‘The relevance of Hume's natural history of religion for cognitive science of religion', Res Philosophica, 92, 653-674. 
Dever, William (2005) Did God Have a Wife? Archaeology and Folk Religion in Ancient Israel (Grand Rapids MI: William Eerdmans Publishing Co.).

Draper, PaUl (1989) 'Pain and pleasure: an evidential problem for theists', Noûs, 23, 331-350.

Draper, Paul (1996) 'The skeptical theist', in Daniel Howard-Snyder (ed.) The Evidential Argument from Evil (Indianapolis: Indiana University Press), 175-192.

Draper, Paul (2008) 'Collins' case for cosmic design', in Paul Draper (ed.) God or Blind Nature? Philosophers Debate the Evidence, The Secular Web, <https://infidels.org/library/modern/paul_draper/no-design.html>.

Draper, Paul (2010) 'Cumulative cases', in Charles Taliaferro, Paul Draper, \& Philip Quinn (eds) A Companion to Philosophy of Religion (Oxford: Wiley-Blackwell), 414-424.

Draper, PAUL (2016) 'Where skeptical theism fails, skeptical atheism prevails', in Jonathan Kvanvig (ed.) Oxford Studies in Philosophy of Religion, VII (Oxford: Oxford University Press), 63-80.

DRAPER, SCOTT \& BAKER, JOSEPH (2011) 'Angelic belief as American folk religion', Sociological Forum, 26, 623-643.

Edgell, Penny, Gerteis, Joseph, \& Hartmann, Douglas (2006) 'Atheists as "other": moral boundaries and cultural membership in American society', American Sociological Review, 71, 211-234.

Eldis, Lee \& WАНАВ, Еsнан (1997) 'Religiosity and fear of death: a theory-oriented review of the empirical literature', Review of Religious Research, 55, 149-189.

Guthrie, Stewart (1980) 'A cognitive theory of religion', Current Anthropology, 21, 181-194.

Harding, Stephen, Flannelly, Kevin, Weaver, Andrew, \& Costa, Karen (2005) 'The influence of religion on death anxiety and death acceptance', Mental Health, Religion \& Culture, 8, 253-261.

Hasker, William (2010) 'Defining "gratuitous evil”: a response to Rhoda', Religious Studies, 46, 303-309.

Holden, Thomas (2010) Spectres of False Divinity: Hume's Moral Atheism (Oxford: Oxford University Press).

Hudson, Hud (2014) 'The father of lies?', in Jonathan Kvanvig (ed.) Oxford Studies in Philosophy of Religion (Oxford: Oxford University Press), 147-166.

IMMERWAHR, JoHn (1996) 'Hume's aesthetic theism', Hume Studies, 22, 327-328.

Justice, William \& LAMBERT, WARREN (1986) 'A comparative study of the language people use to describe the personalities of God and earthly parents', Journal of Pastoral Care, 40, 166-172.

KoENIG, HaRrold (2005) Faith \& Mental Health: Religious Resources for Healing (Conshohocken PA: Templeton Foundation Press).

KraAy, KlaAs (2016) 'God and gratuitous evil (Part 1)', Philosophy Compass, 11, 905-912.

LAW, Stephen (2015) 'The Pandora's box objection to skeptical theism', International Journal for the Philosophy of Religion, 78, 285-299.

LAW, Stephen (2017) 'Skeptical theism and skepticism about the external world and past', Royal Institute of Philosophy Supplements, 81, 55-70.

LuCAS, Aron (2018) 'The argument from cognitive biases', The Secular Web, <https://infidels.org/library/ modern/aron_lucas/cognitive-biases.html>.

MacArthur, John (2005) 'Worshiping', in John MacArthur \& the Master's Seminary Faculty (eds) Pastoral Ministry: How to Shepherd Biblically, The John MacArthur Pastor's Library (Nashville TN: Thomas Nelson, Inc.), 189-203.

Megill, Jason, \& Linford, Daniel (2017) 'On the unimportance of theistic belief', Essays in the Philosophy of Humanism, 25, 1-21.

Morton-Williams, Peter (1960) 'Yoruba responses to the fear of death', Africa: Journal of the International African Institute, 1, 34-35.

Morton-Williams, Peter (1964) 'An Outline of the cosmology and cult organization of the Yoruba', Africa: Journal of the International African Institute, 34, 243-261.

Nielsen, KaI (1990) Ethics Without God, 2nd edn (Amherst NY: Prometheus Books).

Norenzayan, Ara \& Hansen, IAn (2006) 'Belief in supernatural agents in the face of death', Personality and Social Psychology Bulletin, 32, 174-186.

OLSSON, TORD (1999) 'Verbal representation and religious belief: a dilemma in the phenomenology of religion', in E. R. Sand \& J. P. Sørensen (eds) Comparative Studies in the History of Religions: Their Aim, Scope and Validity (Copenhagen: Museum Tusculanum Press), 75-92.

OsarchuK, Michael \& Tatz, Sherman (1973) 'Effect of induced fear of death on belief in afterlife', Journal of Personality \& Social Psychology, 27, 256-260.

Plantinga, Alvin (2000) Warranted Christian Belief (New York: Oxford University Press).

Pососк, J. G. A. (1997) 'Enthusiasm: the antiself of enlightenment', Huntington Library Quarterly, 6o, 7-28. 
RoubeKas, Nickolas (2013) 'Whose theology? The promise of cognitive theories and the future of a disputed field', Religion \& Theology, 20, 384-402.

Rowe, William (1979) 'The problem of evil and some varieties of atheism', American Philosophical Quarterly, 16, 335-341.

SCAlia, ElIZABETH (2013) Strange Gods: Unmasking the Idols in Everyday Life (Notre Dame IN: Ave Maria Press). Schellenberg, John (2015) The Hiddenness Argument: Philosophy's New Challenge to Belief in God (Oxford: Oxford University Press).

Sноок, Jонn (2017) 'Are people born to be believers, or are gods born to be believed?', Method \& Theory in the Study of Religion, 29, 353-373.

Siebert, Donald (1984) 'Hume on idolatry and incarnation', Journal of the History of Ideas, 45, 379-396.

SLONE, D. JASON (2004) Theological Incorrectness: Why Religious People Believe What They Shouldn't (Oxford: Oxford University Press).

TABOR, JAMES (1989) 'The future', in Morton Smith \& R. Joseph Hoffmann (eds) What the Bible Really Says (New York: HarperCollins), 33-52.

van Inwagen, Peter (2002) 'What is the problem of the hiddenness of God?', in Daniel Howard-Snyder \& Paul Moser (eds) Divine Hiddenness: New Essays (Cambridge: Cambridge University Press), 24-32.

Westh, Peter (2014) 'Anthropomorphism in God concepts: The role of narrative' in Armin Geertz (ed.) Origins of Religion, Cognition and Culture (London: Routledge), 396-414.

Whitehouse, HaRvey (1996) 'Rites of terror: emotion, metaphor and memory in Melanesian initiation cults', The Journal of the Royal Anthropological Institute, 2, 703-715.

Wielenberg, Erik (2010) 'Skeptical theism and divine lies', Religious Studies, 46, 509-523.

Wielenberg, Erik (2014) 'Divine deception', in Trent Dougherty \& Justin McBrayer (eds) Skeptical Theism: New Essays (Oxford: Oxford University Press), 236-249.

WIELENBERG, ERIK (2015) 'The parent-child analogy and the limits of skeptical theism', International Journal for the Philosophy of Religion, 78, 301-314.

WiLKs, IAN (2013) 'The global skepticism objection to skeptical theism', in Justin McBrayer \& Daniel HowardSnyder (eds) The Blackwell Companion to the Problem of Evil (Oxford: John Wiley \& Sons), 448-467.

Yandell, Kerth (1990) Hume's 'Inexplicable Mystery': His Views on Religion (Philadelphia: Temple University Press).

Yoder, Don (1974) 'Towards a definition of folk religion', Western Folklore, 33, 2-15.

\section{Notes}

1. We understand classical theism as the view that there exists a unique, omnipotent, omniscient, omnibenevolent, and infinitely loving being who created everything other than herself.

2. For the Abrahamic religions, idolatry is a terrible sin God commands us to avoid. And, as Nielsen summarizes, 'the Jewish and Christian creeds [make] it plain that man lives not for himself alone but was created by God for fellowship with Him. Man's purpose involves the love and acknowledgement of God. To love God is the fundamental reason for man's existence' (Nielsen (1990), 93). Communion with God would bring us into our greatest fulfilment and deepest good. Worshipping an idol, and so a false God, blocks the possibility of such a relationship. We do not suppose these reasons to support (1) are exhaustive.

3. An anonymous reviewer raised an objective to this thought experiment and the application to the argument from idolatry. They wrote,

[Pam] might have a satisfying relationship with Jim, all the while thinking she experiences this with Roy. Likewise, [idolators] might have a satisfying relationship with [some entity other than God], believing they love and worship God. If God is actively deceiving [the idolator] ... then, through no fault of their own, their love and worship are misdirected, but their feelings are sincere.

According to the reviewer, since the believers' feelings are sincere, some theists may argue that the idolator's misdirected love and worship are acceptable to God. However, the reviewer's comment misses our point. We are not concerned with God's judgement of idolatry. Instead, we are concerned with God's instrumental rationality qua God's perfect love. God would seek loving relationship, not because idolatrous behaviour is unacceptable to God, but because those who love seek relationship for love's own 
sake. Moreover, as we explain, the argument from idolatry is not an argument from evil - that is, we are not concerned with whether idolaters are satisfied with their religious beliefs. (Nonetheless, we find plausible the thesis that if God exists, the greatest fulfilment would be achieved through relationship with God.)

4. Kraay draws his second condition, which we adapt for our second condition, from Hasker (2010). The notion of gratuitous evil originates with Rowe (1979). The analogy with gratuitous evil will incline many to offer some variation of sceptical theism in response. We have nothing original to contribute to the debate on sceptical theism (as coined in Draper (1996) ) in this article, but we do note that sceptical theism remains controversial. Although we are convinced that sceptical theism has been successfully answered (Wielenberg (2010), Idem (2014), Idem (2015); Wilks (2013); Hudson (2014); Law (2015), Idem (2017); Draper (2016) ), convinced sceptical theists can reinterpret this article to demonstrate some consequences of giving up sceptical theism or as a reductio of those theistic positions that deny sceptical theism.

5. See Schellenberg (2015), 29-30, for a similar line of argumentation concerning the relationship between the divine hiddenness argument and the problem of evil.

6. Van Inwagen's thought experiments are meant to distinguish the problem of divine hiddenness from the problem of evil. For van Inwagen, the problem of evil, but not the problem of divine hiddenness, can arise in type (a) worlds while the problem of divine hiddenness, but not the problem of evil, can arise in type (b) worlds.

7. As an anonymous reviewer points out, some theists may object that though our cognitive apparatus is contingently arranged, we find the arrangement theology predicts. Reformed theology predicts that we have a faculty for non-inferentially producing God-beliefs, i.e. the sensus divinitatis. Cognitive science of religion has found that we have such a faculty, perhaps vindicating reformed theology (Clark \& Barrett (2010), (2011); Clark (2010); Barrett (2011), 155-156; for a critical response, see Shook (2017)). We respond in three ways.

First, while Clark and Barrett are right that reformed theology predicts the general fact that we possess some cognitive faculty for non-inferentially producing God beliefs, they have not considered whether the particular facts concerning our God-belief faculty are plausible given theism. That is, Clark and Barrett commit what Paul Draper calls the fallacy of understated evidence: they 'successfully identify some general fact about [our cognitive faculties] that is more probable given theism than given naturalism, but all too conveniently ignore other more specific facts about that topic, facts that, given the general fact, are significantly more probable in naturalism than in theism' (Draper (2010), 421-422; also see Draper (2008); Idem (2016); Lucas (2018) ). The argument from idolatry suggests that one particular fact, i.e. our gratuitous inclination to idolatry, is either implausible on classical theism or that God is indifferent to idolatry (in which case, e.g., much of traditional religion is wrongheaded).

Second, supposing reformed theology does predict the particular facts, pre-scientific reformed theologians (e.g. Calvin) had access to the same phenomenology available to religious practitioners now; we should not be surprised if the phenomenology they discussed agrees with the phenomenology described by cognitive science. (Cognitive scientists should worry if this were not the case!) Following the parallel discussion of theodicy in Draper (1989), we should instead ask whether reformed theology is probable given theism. If reformed theology is not probable given theism, then reformed theology's ability to predict the data will not substantially raise the probability of theism, given the data.

Third, Barrett (1999) explains that humans process ideas about God differently under conditions of cognitive load as a by-product of more general constraints imposed by cognitive efficiency. While cognitive efficiency constraints may be inevitable in a naturalistic explanation of our God-belief producing faculty, such constraints are problematic on a theistic model in which God providentially ensures our God-belief producing faculty. Again, God could have endowed us with cognitive faculties allowing us to process ideas about God efficiently and accurately even under conditions of cognitive load. Moreover, Roubekas (2013) argues that the findings in Barrett \& Keil (1996) might explain the Arian controversy: the folk are predisposed against an orthodox understanding of the Trinity. This would be particularly surprising if orthodox Christian theology were true because this would suggest that the folk are cognitively wired so that they are more likely to hold a recognized heretical position from Christian theological history.

8. One might have thought religious activity was motivated by love of God; but since there cannot be a passion whose object is God, and there cannot be actions unmotivated by passions, religious actions cannot be brought about by love of God. Hume scholars agree with our interpretation. For example, Thomas Holden cites passages to support the claim that human passions are not directed towards God 
(Holden (2010), 51). According to Holden, Hume believed that 'God is not merely currently unseen and unknown [on Hume's view] but "Invisib[le] and Incomprehensib[le]" ', unrepresentable by human faculties (ibid., 66). Hume maintained that 'historical religions only succeed in engaging our passions insofar as they present us with sensible forms that cannot be possibly identified with the ultimate first cause or designer' (ibid., 62). Likewise, Siebert and Holden interpret Hume to suggest that God is not the object of any passion and that humans find idolatry natural. According to Siebert, Hume argued that humans are 'idolaters by nature' (Siebert (1984), 381). The incarnation of God in material objects is a kind of divine simulacrum in the physical world enabling religious activity (ibid., 393-394). For Holden, Hume's work implies an argument for moral atheism, according to which the Ultimate cause and sustainer of the universe cannot be an object of moral evaluation (Holden (2010), 49). We do not take a position on whether Holden's interpretation of Hume as a 'moral atheist' is correct or if Hume advanced the various arguments Holden believes to be implicit in Hume's work. Nonetheless, we note that our article is consistent with and mutually supportive of Holden's interpretation.

9. Throughout the Natural History, various pagan religions, such as the ancient Greeks (NHR IX.4) and Egyptians (NHR IX.2), are identified as superstitions. For Hume, Catholicism is another superstition. Hume's claim that Catholicism is a superstition echoes previous Protestant critiques, but as discussed below, Hume equally takes aim at Protestants. In Hume's History of England, he discusses either the 'catholic superstition' (HE XXXIII 237) or the 'Romish superstition' (HE XXXIV 300; 305). Throughout his Natural History, Hume identifies particular Catholic practices - such as the Eucharist (NHR XII.2-3) and the veneration of saints (NHR X.3) - as superstitions. In his Of Superstition and Enthusiasm, Hume argues that superstitions elevate their clergy to higher statuses than other religions elevate their clergy. Given too high a standing, clergy are prone to political corruption. Priests elevated into positions of high authority become tyrants, their actions resulting in endless religious wars (SE 77-79). Hume asserts the Jesuits have become tyrants in France and identifies specific groups of Catholics, such as the Molinists, as examples of the superstitious. The one notable exception are the Jansenists, whom Hume identifies as preserving 'alive the small sparks of the love of liberty' in France (SE 80).

10. We interpret Hume's 'melancholy' as interchangeable with Hume's 'despair', as described in his Treatise.

11. As expected from his letter to Mure, superstition does not arise from some indirect passion whose object is God.

12. Hume notes that Jews and 'Mahometans' (Muslims) ban all 'the arts of statuary and painting, and [do not allow] the representations, even of human figures, to be taken by marble or colours; lest the common infirmity of mankind should produce idolatry' (ibid.). Religions allowing statuary, painting, and other representations become idolatrous because God is not the actual object of their worship. Hume presumably has in mind the Catholics, whom the Protestants had condemned for their idolatry (saints, statues of the Virgin Mary, etc.). Hume tells us that the idols of the Catholics are at least as bad as those of pagans: 'But what strange objects of adoration are cats and monkeys? says the learned doctor. They are at least as good as the relics or rotten bones of martyrs, answers his no less learned antagonist' (NHR XII.7).

13. For a book length discussion, see Slone (2004).

14. Elsewhere, De Cruz arrives at a view distinct from Boyer's, but not in ways relevant for our purposes. See De Cruz (2013).

15. God is infinite, perfect, limitless, omnipotent, unchanging, non-material, omniscient, and so on.

16. We've described the questionnaire and narrative recall tasks as if Barrett and Keil performed them in a particular order. Barrett and Keil explain that they reversed the ordering to control for possible priming effects (Barrett \& Keil (1996), 226).

17. For overviews, see Boyer (2001) and Atran (2002), ch. 4.

18. In cultures that do not have an explicit belief in an afterlife for particular persons, people have often believed in a different kind of future life, for example, that their society continues after their death. For example, Tabor (1989) discusses ancient Israelite religion, in which Israelite religion 'functioned very well [without the idea of an eternal life in heaven] for more than a thousand years'. According to Tabor, various rituals and practices were constructed to find favour with Yahweh.

19. For reviews on data linking religion and fear of death, see Ellis \& Wahab (1997); Argyle \& Beit-Hallahmi (1997), 193-197; for psychological literature linking anxiety and religious belief, see Koenig (2005), 45-48, 83-84.

20. An important caveat: Harding et al. only compared Episcopalians, from a single church, with other Episcopalians from the same church. One should not infer, for example, that atheists would be less 
anxious if exposed to more religion. Osarchuk and Tatz (1973) found that, after subjects were exposed to graphic death imagery, those who believed in an afterlife before the experiment reported a stronger belief in the afterlife after the experiment. Among non-believers, Osarchuk and Tatz found no statistically significant changes. Similarly, Norenzayan and Hansen (2006) found that subjects who report a prior belief in supernatural agents germane to a particular religion (e.g. the Abrahamic God), when primed to think about death, report 'stronger belief in supernatural agents' (ibid., 183), even if the agents are culturally foreign. However, the beliefs of non-religious individuals remained unchanged, whether for culturally germane or culturally foreign supernatural agents.

21. One might have thought, since the imagination swelled with some 'confused conception' corresponding to nothing in the Earthly ('sublunary') realm, Hume is describing the enthusiast's conception of God. However, in light of the letter to Mure, the object of the 'confused conception' must be something other than God. Perhaps enthusiasm should be understood as a kind of madness arising from the inability for God to be the object of one's love ('the fanatic madman delivers himself over, blindly and without reserve, to the supposed illapses of the Spirit and to inspiration from above'; SE 76).

22. Contrary to the interpretation we've provided, Hume sometimes suggests a degraded form of God as the object of the passions involved in enthusiasm. For example, Hume writes that hope and fear 'agitate [the enthusiast's] breast when [enthusiasts] think of the Deity', so they 'degrade [God] into a resemblance with themselves' and thereby render God 'more comprehensible', or they may 'exult with Vanity in esteeming themselves [God's] peculiar Favourites' (WC 18). Again, worshipping a more comprehensible idol in place of God is a central theme. Earlier, we attributed to Hume the view that the object of enthusiasm is the self. Here, Hume seems to say that the object of enthusiasm is either the self or a degraded form of God. The two interpretations might be reconciled if the degraded form of God is taken to be the self, or one might interpret Hume as changing his view over time. On the other hand, note that if the passions involved in enthusiasm do involve a degraded form of God as the object, Hume's conception of enthusiasm may still be empirically supported by appealing to the experiments discussed in the section on superstition.

23. Biblical scholars have argued that prohibitions discussed in the Bible provide a glimpse into which sorts of transgressions were commonplace in ancient Israel, e.g. Dever (2005), 46-51. 